\title{
КОНТЕКСТНИЙ АНАЛІЗ АБРЕВІАТУРИ COVID-19 ТА ЛЕКСИЧНИХ ВАРІАНТІВ ЇЇ НА ПЕРЕТИНІ ЛЕКСИКОЛОГІї, СЛОВОТВОРУ Й СИНТАКСИСУ
}

\author{
Омельчук С. А., Мандич Т. М.
}

\section{ВСТУП}

Починаючи з другої половини 2020 року, вітчизняні й зарубіжні вчені-мовознавці активно спрямовують свої зусилля на різноаспектне дослідження лексики, пов'язаної з COVID-19. Зокрема, у наших попередніх наукових розвідках ми дослідили особливості функціювання ад’єктивів «пандемічний» і «пандемійний» у сучасному українському лексиконі ${ }^{1}$, вербалізації концепту «пандемія covid-19» у французькій мові присвячено роботу Л. Коккіної ${ }^{2}$, лексичним інноваціям у французькій мові - Т. Весни та Т. В. Телецької; в англійській мові - I. Козубай та А. Хаджи ${ }^{4}$; порівняльний аспект на матеріалі різних мов (проаналізовано українські та словацькі тексти) репрезентовано в статті Л.Ходи ${ }^{5}$ В українському мовознавстві функціювання актуальних медичних лексем на рівні офіційних

1 Омельчук С. А. Відіменникові ад'єктиви «пандемічний» і «пандемійний» у сучасному українському лексиконі. Актуальні питання суспільних наук та історії медицини. Спільний украӥнсько-румунський науковий журнал. Серія ”Філологічні науки" || Current issues of Social studies and History of Medicine. Joint UkrainianRomanian scientific journal. Series "Philological sciences" / Редколегія: А. Мойсей, Ш. Пуріч. Чернівці-Сучава: БДМУ. 2020. № 3 (27). С. 15-18.

2 Коккіна Л. Р. Вербалізація концепту «пандемія COVID-19» у французькій мові як перекладацька проблема. International scientific and practical conference "Challenges of philological sciences, intercultural communication and translation studies in Ukraine and EU countries» : conference proceedings, October 30-31, 2020. Venice : Izdevnieciba «Baltija Publishing», 2020. P. 213-216. http://baltijapublishing.lv/omp/ index.php/bp/catalog/view/69/1646/3656-1

${ }^{3}$ Весна Т., Телецька Т. Лексичні інновації періоду коронавірусної пандемії. Записки з романо-германської філологї̈. 2020. Вип. 1 (44). С. 82-89.

${ }^{4}$ Козубай І. В., Хаджи А. Ю. Дослідження структурно-семантичних особливостей новоутворень сучасної англійської мови. Вісник ЛНУ імені Тараса Шевченка. Філологічні науки. 2020. № 3 (334). С. 19-26.

${ }^{5}$ Хода Л. Мова реклами в часи пандемії коронавірусу COVID-19 (на матеріалі українських та словацьких текстів). Південний архів (філологічні науки). 2020. № 82. C. $130-134$. 
документів і в медійному просторі фрагментарно висвітлили О. П'ятецька ${ }^{6}$, О. Тур ${ }^{7}$.

Актуальність нашого дослідження визначена тим, що вживання лексем, тематично пов'язаних зі світовою пандемією коронавірусу, $\epsilon$ досить поширеним у лексиконі сучасних українців. Високу частотність використання нових слів медичного спрямування пандемійного 2020 року підтверджує й опитування, що ми провели в соціальних мережах за допомогою Google-форми. Зокрема, респондентам було запропоновано назвати від одного до трьох нових слів 2020 року, що стали популярними й найбільш поширеними у власному мовленні. Аналіз понад 100 відповідей учасників опитування дав змогу констатувати, що більшість становлять слова, прямо чи опосередковано пов'язані з коронавірусною тематикою. Це:

- іменники - назви хвороби й похідні прикметники: коронавірус, COVID-19 (Covid-19, Covid,), ковід, корона;

- іменники - назви медичних станів, процесів та конкретних предметів: карантин, пандемія, маска, ПЛР/ПЛР-тест, антисептик, вакцинаиія, вірус, санітайзер, сатурачія, ШВЛ;

- слова і словосполучення, що позначають назви соціальних явищ, викликаних пандемією: локдаун, дистаниійне навчання, дистаниійка, самоізоляція, соиіальна дистаниія, онлайн, безробіття, дистанційна освіта, дистаниія, ізоляція, криза, мудл, ZООМ.

Поодинокі відповіді респондентів пов'язані з молодіжним сленгом (ауф, краш), назвами процесів і конкретних понять іншомовного походження (булінг, інклюзія, коуч, лінк, прокрастинація, рандомно), новими орфографічними і граматичними варіантами, що відбиває Український правопис 2019 року (етер, кандидатка, катедра, педагогиня). До того ж окремі учасники опитування зазначили, що змін у їхньому лексиконі не відбулося.

Отже, слова, що прямо вказують на коронавірусну хворобу, становлять $21,2 \%$; слова, тематично пов'язані з хворобою - $53,2 \%$, інші слова, різні за змістом, функцією й тематичним спрямуванням, становлять $25,6 \%$.

${ }^{6}$ П'ятецька О. Українське законодавство в умовах національного карантину: лексико-семантичний аналіз. Актуальні питання гуманітарних наук. 2020. Вип. 30. Том 3. С.36-40.

7 Тур О. Інтернет-сайти як джерело поповнення загальномовного словника лексичними скороченнями. Тези 72-ої наукової конференції професорів, викладачів, наукових прачівників, аспірантів та студентів університету, присвяченої 90-річчю Національного університету «Полтавська політехніка імені Юрія Кондратюка» (Полтава, 21 квітня - 15 травня 2020 р.). Полтава: Національний університет імені Юрія Кондратюка, 2020. Том 2. С. 311-312. 
Мета нашого дослідження - на матеріалі сучасних інтернет-текстів інформаційного характеру різножанрового спрямування здійснити контекстний аналіз абревіатури COVID-19 та лексичних варіантів іï на перетині лексикології, словотвору й синтаксису. Науководослідницькими завданнями $є$ визначити семантико-категорійний потенціал лексеми COVID-19 та з'ясувати іiі лексико-словотвірні особливості; дослідити структурно-смислові відношення між лексичними варіантами абревіатури COVID-19; проаналізувати дериваційний потенціал лексичних варіантів цієї абревіатури; схарактеризувати лексико-семантичну і синтаксичну сполучуваність абревіатури COVID-19 та лексичних варіантів

\section{1. Семантико-категорійний потенціал лексеми COVID-19}

Загальновідомо, що процес творення нових слів зумовлений появою в поняттєвій системі певної мови нових елементів, що потребують відповідних найменувань. Зокрема, це стосується й лексеми COVID-19, яка репрезентує нове явище світового рівня, що виникло на межі 2019-2020 років. Перші звістки про зафіксовані випадки не встановленого в медичній науці захворювання спричинили появу у світовому інформаційному просторі різних лексем, якими позначали збудник інфекційної хвороби, як-от:

- пневмонія невідомого походження (У місті Ухань у Центральному Китаї зафіксували 27 випадків захворювання на пневмонію невідомого походження (Інформаційне агентство «Українські національні новини», 31.12.2019);

- 2019-nCoV (саме такою умовно маркованою абревіатурою на початку січня 2020 року китайська влада визначила коронавірус як причину хвороби ${ }^{8}$;

- гостра респіраторна хвороба COVID-19 - один із перших українських термінів, зафіксований у розпорядженні Кабінету Міністрів України від 3 лютого 2020 р. № 93-р «Про заходи щодо запобігання занесенню і поширенню на території України гострої респіраторної хвороби COVID-19, спричиненої коронавірусом SARS-CoV-2»;

- коронавірусна хвороба (COVID-19) - офіційний український термін, зафіксований у Стандартах медичної допомоги «Коронавірусна хвороба (COVID-19)», затверджених наказом Міністерства охорони здоров'я України від 28.03.2020 № 722 «Організація надання медичної допомоги хворим на коронавірусну хворобу (COVID-19)», у Законі України від 17.03.2020 № 530-IX «Про внесення змін до деяких законодавчих актів України, спрямованих на запобігання виникненню

\footnotetext{
${ }^{8}$ https://www.euro.who.int/de/health-topics/health-emergencies/coronavirus-covid-19
} 
і поширенню коронавірусної хвороби (COVID-19)». Ці документи містять термінну назву коронавірусна хвороба (COVID-19), а у Стандартах медичної допомоги зафіксовано термін коронавірусна інфекиія COVID-19, а також COVID-19 як скорочену назву хвороби, яку спричинює коронавірус SARS-CoV-2. До того ж назву коронавірусна інфекція COVID-19 марковано як тимчасову.

Водночас лексема коронавірус, яка набула широкого поширення в 2020 році, не $\epsilon$ повністю новою. Пандемія коронавірусної інфекції лише актуалізувала вживання цього найменування. Наприклад, у статті «Коронавірусні інфекції: близькосхідний респіраторний синдром, спричинений MERS-CoV», опублікованій у 2015 році у фаховому медичному виданні України «Мистецтво лікування», натрапляємо на такі поняття, як коронавірусна інфекиія, коронавіруси, штам коронавірусу 9 . Також на ресурсі «Радіо Свобода» подано розширену словникову статтю, яка повідомляє про вже зафіксовані спалахи коронавірусу та вказують на вже відомі фахівцям медичні поняття, позначені абревіатурами MERS-CoV та $S A R S-C o V$ : «Коронавірус - це родина вірусів, до якої належить вірус SARS-CoV-2, з яким ми маємо справу сьогодні. До цієї ж родини належить також коронавірус близькосхідного респіраторного синдрому MERS-CoV, який уперше діагностували в 2012 році в Саудівській Аравії, і коронавірус тяжкого гострого респіраторного синдрому SARS-CoV, який спричинив спалах епідемії у 2003 році» ${ }^{10}$. Також Словник термінів, розміщений на цьому ресурсі, пропонує примітивну дефініцію COVID-19: «COVID-19 це назва пандемічної коронавірусної хвороби, що поширилася в усьому світі. Вона була викликана новим штамом коронавірусу, що походить 3 міста Ухань у Китаї» ${ }^{11}$.

Медичну абревіатуру-термін, що містить інформацію про нове захворювання, подають як SARS-CoV-2 - скорочення термінного словосполучення severe acute respiratory syndrome-related coronavirus 2 (укр. коронавірус тяжкого гострого респіраторного синдрому-2)12. У публіцистичному й розмовному стилях мовлення поширеною $\epsilon$ абревіатура-ініціалізм COVID-19, утворена від англійського термінасловосполучення coronavirus disease шляхом усічення перших двох літер двох коренів складного слова латинського походження coronavirus (укр. коронавірус) і першої літери наступного слова $\underline{\text { disease }}$

9 Дуда О. К., Коцюбайло Л. П. Коронавірусні інфекції: близькосхідний респіраторний синдром, спричинений MERS-CoV. Мистещтво лікування. 2015. № 7-8 (123-124). C. 4-11.

${ }^{10} \mathrm{https}$ ://www.radiosvoboda.org/a/koronavirus-terminy-slovnyk/30520097.html

11 Там само.

12 Там само. 
(укр. хвороба, захворювання) та з додаванням числа 19, що вказує на рік виявлення першого випадку захворювання:

COVID-19 $\leftarrow$ (co)rona(vi)rus (d)isease +19

Сучасний інтернетовий простір фіксує кілька варіантів написання цієї абревіатури:

- великими літерами (COVID-19), наприклад: Як повідомила пресслужба Полтавської ОДА, за останню добу в області лабораторно підтверджено 310 нових випадків захворювання на COVID-19 (Інтернет-видання «Полтавщина», 13.12.2020);

- $з$ великої літери (Covid-19), наприклад: Як почувається украӥнецьь, який один із перших вакцинувався від Covid-19 (Інформаційнорозважальний портал NEWSYOU.INFO, 13.12.2020);

Проте згідно 3 правописною нормою чинного «Українського правопису» орфографічно правильним оформленням цієї абревіатури $\epsilon$ перший варіант, оскільки «складноскорочені назви, утворені 3 початкових (ініціальних) букв, пишемо великими буквами» ${ }^{13}$.

Водночас якщо латинізм coronavirus перенесено до української мови без зміни форми й семантики (коронавірус $\leftarrow$ coronavirus), то українське слово-неологізм ковід утворено шляхом транслітерації англійськомовної ініціальної абревіатури $C O V I D$ - заміни англійських літер літерами української абетки (ковід $\leftarrow$ COVID). Такий спосіб перекладання вчені-мовознавці вважають найбільш простим варіантом, оскільки цей шлях обирають тоді, коли скорочення загальновідоме й перекладачеві не потрібно шукати значення відповідного слова в словникові, а в процесі перекладання він лише замінює англійські букви літерами рідної мови ${ }^{14} .3$ огляду на це лексема ковід не підлягає розшифруванню й уважати їі повноцінною абревіатурою недоцільно.

\section{2. Структурно-смислові відношення} між лексичними варіантами абревіатури COVID-19

Медичний термін COVID-19 як різновид коронавірусної хвороби утворює синонімне об'єднання лексем як інтернаціонального позначення, так i адаптованих українськомовних назв: ковід, коронавірус, коронавірус COVID-19, коронавірус SARS-CoV-2; коронавірусна інфекиія 2019-nCoV, коронавірусна хвороба, коронавірусна хвороба COVID-19, гостра респіраторна хвороба COVID-19. Наприклад: Ознаки для визначення регіону зі значним

${ }^{13}$ Український правопис / НАН України. Київ : Наук. думка, 2019. С. 90.

14 Ніколаєва Т. М. Перекладацькі аспекти сучасний англійських абревіацій. Науковий вісник Міжнародного гуманітарного університету. Серія «Філологія». 2018. № 37. T. 3. С. 109. 
потиренням COVID-19 (MO3 України, 18.09.2020); Оперативна інформачія про поширення коронавірусної інфекції 2019-nCoV (MO3 України, 18.09.2020); У зв'язку із пандемісю коронавірусу COVID-19 в Украӥні, як $і$ в багатьох краӥнах світу, запровадили карантин (УКРІНФОРМ, 10.10.2020); Лікар Білого дому Шон Конлі повідомив, що президент США Дональд Трамп заявляє про чудове самопочуття, а в його організмі виявлені антитіла до захворювання COVID-19, викликаного итамом коронавірусу SARS-CoV-2 (УКРІНФОРМ, 10.10.2020); За даними Центру громадського здоров'я, станом на 18 вересня в Україні зафіксовано 3228 нових випадків коронавірусної хвороби COVID-19 (МО3 України, 18.09.2020); «3а минулу добу зареєстровано 112 нових випадків захворювання на гостру респіраторну хворобу COVID-19», - йдеться y повідомленні (УКРІНФОРМ, 10.10.2020).

Наші спостереження за мовленням сучасних українців дають змогу виявити й контекстуальні лексичні синоніми до абревіатури COVID-19, представлені такими варіантами: нежданий коронний гість, корона, уханський вірус, уханська пошесть, китайський вірус, китайська чума тощо, здатні передавати різні додаткові смислові відтінки.

Усі вони хоч $\mathrm{i}$ мають ідентичне значення й можуть бути взаємозамінними, проте в активному мовленні сучасних українців закріпилися два лексичні відповідники англізма COVID-19, зокрема ковід і коронавірус, що $є$ найбільш поширеними в аудіовізуальних і текстових джерелах. Ці слова-еквіваленти виникли в результаті семантичної асиміляції англізма COVID ( $\rightarrow$ укр. ковід) і латинізма coronavirus ( $\rightarrow$ укр. коронавірус), зокрема фонетичної та морфологічної адаптації до системи мови-реципієнта. У сучасній українській мові $\epsilon$ чимало прикладів успішної асиміляції новітніх англійських слів, що протягом останніх років усе активніше набувають кириличного оформлення, проте ще не зафіксовані в словниках: GOOGLE (Google) $\rightarrow$ гугл; FACEBOOK (Facebook) $\rightarrow$ фейсбук; Telegram $\rightarrow$ телеграм; Viber $\rightarrow$ вайбер; WhatsApp $\rightarrow$ вaųan та ін.

Кінцевим етапом адаптації будь-якого іншомовного слова вченімовознавці вважають фіксацію його в лексикографічних джерелах української мови. Це означає, що «слово цілком пристосувалося до мовної системи мови-реципієнта» ${ }^{15}$.

Цей процес $\epsilon$ нормальною ознакою пристосування новітніх англізмів до мовної системи української мови. Зокрема, окремі

${ }^{15}$ Молоткіна Ю. О. Різні способи написання новітніх англіцизмів в українській мові. Науковий вісник ДДПУ імені І. Франка. Серія «Філологічні науки». Мовознавство. 2017. № 7. С. 120. 
англізми, які давно запозичені й набули кириличного оформлення в українській мові, зафіксовані у вітчизняних лексикографічних джерелах, наприклад, у словникові «Нові слова та значення» ${ }^{16}$, уже не потребують написання англійською мовою, наприклад: диджей $(\leftarrow D J$ $\leftarrow$ Disc Jockey), інтернет ( $\leftarrow$ Internet), копірайm $(\leftarrow$ copyright), медіа $(\leftarrow$ media $)$, niap $(\leftarrow P R \leftarrow$ public relations $)$, тинейджер $(\leftarrow$ teenager $)$, чизкейк $(\leftarrow$ cheesecake) та ін.

\section{3. Дериваційний потенціал лексичних варіантів абревіатури COVID-19}

Порівняно з іменниковими й похідними прикметниковими формами інше частиномовне вираження слів на позначення коронавірусної хвороби не є поширеним. Проте засвідчуємо здатність лексеми ковід-19 утворювати інфінітивну форму ковідити. Наприклад: Потрібно заставити владу прачювати, а не ковідити (коментар користувача до публікації «Чому влада любить дистанційку?»; ukblow.info, 10.09.2020). Ця лексема має процесуальне значення і вступає в синонімійні відношення з дієсловом хворіти, указуючи на причину й характер нездужання.

Творення особових форм дієслова ковідити стало продуктивним у кінці 2020 року напередодні зимових свят. Окремі жанри календарнообрядового циклу, серед яких є колядки, зазнали осучаснення. Зокрема, текст пісні відтепер може містити форму I особи однини теперішнього часу ковідую:

Ковідую-ковідую, антисептик носом чую.

Карантин очима бачу, дайте маску, бо заплачу.

(Інтернет-портал «Na Парижі», 28.10.2020)

Ковідую, ковідую,

я вже носом ніи не чую.

(Інтернет-портал «Na Парижі», 28.10.2020).

Активізації дериваційних процесів сприяла фонетична подібність лексем колядую та ковідую.

До того ж у всемережжі натрапляємо й на вживання форми III особи однини ковідить. Наприклад: Свропа знову ковідить але є позитив... (Особистий блог А. Ярмака).

Наведемо кілька прикладів словотвору в іменниковій парадигмі, акцентуючи увагу на стильовому маркуванні похідних лексем. Звертаємо увагу на творення іменника ковідниия від лексеми ковід за допомогою суфіксів - $\boldsymbol{H}_{-}$та -uи -:

${ }^{16}$ Нові слова та значення : словник / Ін-т укр. мови НАН України ; уклали: Л. В. Туровська, Л. М. Василькова. Київ: Довіра, 2009. 271 с. 
Ковід-ковід-ковідниця,

гарна в масиі молодиця,

а без маски не така,

дайте антисептика.

(Інтернет-портал «Na Парижі», 28.10.2020)

Від цієї ж основи 3 додаванням суфікса $-\kappa-$ утворено іменник ковідка, який фіксуємо з-поміж актуальної лексики, поданої в публікації «Словник епохи коронавірусу: 20 термінів, які завжди нагадуватимуть про весну-2020»: COVID-19 ("ковідка") - хвороба, яку викликає Sars-CoV-2 (Інтернет-портал «BBC NEWS Україна, 11.04.2020). Попри те, що цей неологізм також називає хворобу, його номінативна функція доповнена ознаками розмовного стилю, а англійськомовний медичний термін семантично, структурно та графічно адаптовано до закономірностей української мови.

Лексеми коронавірус та ковід стали основою для творення назв осіб - короніали та ковідіали, що за будовою та функцією подібні до іменника міленіали, яким відповідно до теорії поколінь називають покоління Y - людей, що народилися в період з 1981 по 1994-2000 роки ${ }^{17}$. Доповнення генераційної теорії новими термінами висвітлено в медійних матеріалах, зокрема: Короніали або ковідіали - покоління дітей, які народяться після пандемії Covid-19 (Gazeta.ua, 22.04.2020). До того ж основа ковід- вступає в словотвірні зв'язки 3 непродуктивним іменниковим запозиченим суфіксом -om/-iom на означення особи, що характеризується яскраво вираженою негативною оцінкою, зокрема неологізм ковідіот утворено за аналогією до іменників живоглот, idiom, кашалот, кinpiom, компатріот, nampiom, у яких цей суфікс у процесі засвоєння ввійшов до складу кореня. Наприклад: Путін повівся, як класичний ковідіот, - коментує журналіст Ігор Яковенко, 69 років. - Не зрозуміло, для чого було вдягати костюм хімзахисту, в якому він мав вигляд клоуна (Gazeta.ua, 22.04.2020). Спостерігаючи за словотвірною валентністю нових слів 3 основами ковід- і корона-, констатуємо, що за принципом аналогії (відповідно до моделі $N+$ суфіксоїд -навт: астронавт, океанавт, космонавт і под.) утворено й іменник коронавт, що має негативну конотацію (порівняймо: алконавт у значенні алкоголік): Коронавт Путін. Візит президента викликав насмішки (Gazeta.ua, 22.04.2020).

Неологізми, утворені від лексеми ковід, можуть переходити й до розряду власних назв, як-от жіноче ім'я Ковідія. Наприклад: “Ковідія

17 Денисенко М. П., Давиденко Н. В. Теорія поколінь та який іiі вплив на сучасний бізнес. Економіка та держава. 2020. № 1. С. 46-49. URL: http://www.economy.in.ua/pdf/1_2020/10.pdf 
або Каранта": украӥнська зіркова пара розсекретила стать майбутньої дитини та поділилася думками про ім'я (Amazing-Ukraine, 01.06.2020).

Дериваційну спроможність лексеми ковід у сучасній українській мові засвідчує близько 150 хештегів у дописі від 10.07.2020 спільноти «How-how» соціальної мережі «Фейсбук». Широкий спектр лексичних новотворів з основною ковід- репрезентовано такими словотвірними моделями:

1) $\mathrm{TO}_{\mathrm{N}}$ ковід- + іншомовний суфіксальний формант -исm 'особа - носій процесуальної ознаки': ковідист;

2) $\mathbf{T O}_{\mathbf{N}}$ ковід- + іншомовний суфіксальний формант -изм 'назва явища суспільного життя': ковідизм;

3) $\mathrm{TO}_{\mathbf{N}}$ ковід- + асемантична суфіксальна зв'язка -ал- + суфіксальний формант -icm 'особа - носій процесуальної ознаки': ковідаліст;

4) префіксальний формант нон- + $\mathbf{T} \mathbf{O}_{\mathbf{N}}-$ ковідист 'особа - носій процесуальної ознаки': нонковідист;

5) префіксальний формант нон- $+\mathbf{T O}_{\mathbf{N}}$-ковідизм 'назва явища суспільного життя': нонковідизм;

6) $\mathbf{T O}_{\mathbf{N}}$ ковід - + суфіксальний формант -янин 'особа - носій процесуальної ознаки': ковідянин;

7) $\mathbf{T O}_{\mathbf{N}}$ ковід- + іншомовний суфіксальний формант -лог 'особа носій процесуальної ознаки': ковідолог;

8) $\mathrm{TO}_{\mathbf{N}}$ ковід- + іншомовний суфіксальний формант -цевт 'особа - носій процесуальної ознаки': ковідоцевт;

9) основоскладання 3 першим компонентом ковід- + інтерфікс о:

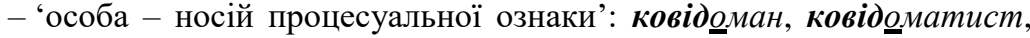
ковідопат, ковідопсих, ковідохам;

- 'предмет': ковідоблок, ковідопаспорт, ковідотруна, ковідосептик;

- 'процес': ковідобій, ковідоблеф, ковідоббор, ковідобунт, ковідоглобалізм, ковідогра, ковідожиття, ковідзахист, ковідозлочин, ковідолайф, ковідообсесія, ковідопатологія, ковідоплан, ковідополон, ковідопотік, ковідорай, ковідоранг, ковідорасизм, ковідорежим, ковідорейтинг, ковідорік, ковідорух, ковідосвіт, ковідосепт, ковідосервіс, ковідостатус, ковідостоп, ковідострім, ковідострус, ковідотактика, ковідодренія, ковідохвиля;

- 'стан': ковідожах, ковідоляк, ковідомарення, ковідосмерть, ковідостан, ковідострах, ковідострес;

- 'збірне поняття': ковідосуд;

10) основоскладання 3 першим компонентом ковід(без інтерфікса):

- 'особа - носій процесуальної ознаки': ковід-естет; 
- 'процес': ковід-архаїка, ковід-етика;

- 'збірне поняття': ковід-армія, ковід-уряд;

11) основоскладання 3 першим компонентом префіксоїдом + інтерфікс о + -ковід 'стан': тираноковід, феміноковід;

12) основоскладання 3 першим компонентом префіксоїдом (без інтерфікса) + -ковід 'процес': автоковід, акваковід, андроковід, демоковід, псевдоковід, самоковід;

13) словоскладання 3 першим компонентом кові - у ролі префіксоїда (без інтерфікса) 3 усіченням кінцевої приголосної фонеми першого компонента [д]: ковідарунок, ковідрама, ковідумка, ковідурень, ковідень, ковітактика.

Зазначимо, що чимало нових похідних слів-іменників 3 компонентом ковід-, які ще не зафіксовані в лексикографічних джерелах, утворено відповідно до внутрішніх механізмів словотворення за аналогією до регулярних чи нерегулярних словотвірних моделей, наявних у системі мови. Наприклад:

ковідолітика (на зразок аналітика, політика, проклітика);

ковіліція (на зразок коаліція, поліція);

ковідляндія (на зразок кідляндія, онландія, спортландія);

ковідоманія (на зразок ігроманія, кіноманія, наркоманія).

Словниковий склад української мови 2020 року активно поповнився й новими словами-прикметниками 3 компонентом ковід-, утвореними шляхом власних словотвірних можливостей:

1) префіксальний формант + ковід-н-ий: аковідний, андроковідний, безковідний, гестоковідний, гетероковідний, гіперковідний, гіпоковідний, гомоковідний, зооковідний, нековідний, недоковідний, параковідний, позаковідний, понадковідний, псевдоковідний, суперковідний, трансковідний, феміноковідний;

2) перший компонент ковід- у ролі префіксоїда + інтерфікс о + прикметник: көвідㅁахисний, ковідогендерний;

3) перший компонент ковіס- у ролі префіксоїда (без інтерфікса) + прикметник: ковідетичний.

Починають функціювати в розмовному мовленні сучасних українців, забезпечуючи процес комунікації, також дієслова на позначення перебігу хвороби 3 кореневою морфемою ковід-, утворені: a) суфіксальним способом (ковідити); б) префіксальним способом (заковідити, розковідити). Наприклад: ковідити більще місяия, раптово заковідити, уся родина розковідилася.

Актуалізованим у мовленні стає й відприкметниковий прислівник ковідно (почуватися ковідно), що слугує твірною базою для можливих нових похідних, утворених за продуктивною моделлю а-(без-) + $\mathbf{T O}_{\text {Adv }}$ : аковідно, безковідно. 
Отже, твірна основа ковід- має чималий дериваційний потенціал й активно вступає в словотвірні зв'язки, утворюючи за регулярними чи нерегулярними словотвірними моделями нові похідні, що використовують мовці в процесі спілкування. Такі похідні, зумовлені певним мовленнєвим контекстом (здебільшого розмовним), хоча і мають типову для українських слів словотвірну структуру, проте належать до контекстуальних, які ще не фіксують словники. Це означає, що лексема ковід і похідні від неї поступово втрачають ярлик власне медичного терміна.

\section{4. Лексико-семантична й синтаксична сполучуваність абревіатури COVID-19 та лексичних варіантів їі}

Сполучуваність, або комбінаторика, за Г. Дидик-Меуш, «дає змогу дослідникові здійснити грунтовний семантичний опис; водночас вона сама слугує доказом, підтвердженням правильності цього опису» ${ }^{18}$. Цілком погоджуємося 3 думкою вченої, що «аналіз сполучуваності дозволяє достовірно встановити семантичну структуру будь-якого слова - зафіксованого і не зафіксованого лексикографічно» 19.3 огляду на зазначене дослідимо особливості сполучуваності абревіатури COVID-19 та лексичних варіантів іiі ковід і коронавірус з іншими словами у складі різних синтаксичних побудов.

Лексеми COVID-19, ковід і коронавірус можуть виконувати роль головного компонента, маючи при собі лівобічний поширювач узгоджений ад'єктив, що вказує на якісну або відносну ознаку (лівобічний поширювач ад'єктив + головний компонент субстантив COVID-19 / ковід / коронавірус): небезпечний COVID-19 / ковід / коронавірус, підступний COVID-19 / ковід / коронавірус, прихований COVID-19 / ковід / коронавірус, смертельний COVID-19 / ковід / коронавірус, страшний COVID-19 / ковід / коронавірус, тривалий COVID-19 / ковід / коронавірус, тяжкий COVID-19 / ковід / коронавірус. Менш поширеними є конструкції:

a) 3 правобічним поширювачем - локативною синтаксемою: COVID-19 / ковід / коронавірус в Украӥні, COVID-19 / ковід / коронавірус в Eвропі, COVID-19 / ковід / коронавірус в армї̈;

б) 3 правобічним поширювачем - синкретичним компонентом 3 об'єктно-атрибутивною семантикою морфологічно експлікованим

18 Дидик-Меуш Г. Сполучуваність vs комбінаторика для розвитку історії української мови. Украӥна: культурна спадщина, національна свідомість, державність / гол. ред. Ігор Соляр; НАН України, Ін-т українознавства ім. І. Крип’якевича. Львів, 2019. Вип. 32. С. 293.

${ }^{19}$ Там само. 
родовим прийменниковим відмінком: COVID-19 / ковід / коронавірус проти мерів.

Виявляючи власні семантико-синтаксичні можливості, іменники COVID-19, ковід і коронавірус у формі називного відмінка $є$ також головним компонентом у структурі граматичного центру речення: COVID-19 / ковід / коронавірус наступає, COVID-19 / ковід / коронавірус зачекає, COVID-19 / ковід / коронавірус забрав життя.

Водночас найбільш продуктивними в сучасному українському мовленні є конструкції, у яких лексеми COVID-19, ковід і коронавірус виконують роль залежного об'єктного компонента. Наприклад:

1) у формі знахідного відмінка:

- як безприйменниковий об'єктний компонент при дієсловах на позначення фізичного стану людини: переносити COVID-19 / ковід / коронавірус, подолати COVID-19 / ковід / коронавірус;

- як об'єктний компонент із прийменником на при дієсловах на позначення фізичного стану людини: хворіти на COVID-19 / ковід / коронавірус, перехворіти на COVID-19 / ковід / коронавірус;

- як присубстантивний об'єктний компонент: а) із прийменником на: хворий на COVID-19 / ковід / коронавірус, тест на COVID-19 / ковід / коронавірус, тестування на COVID-19 / ковід / коронавірус, niдозра на COVID-19 / ковід / коронавірус; б) із прийменником про: інформація про COVID-19 / ковід / коронавірус, новини про COVID-19 / ковід / коронавірус, міфи про COVID-19 / ковід / коронавірус;

- як приадвербативний об'єктний компонент із прийменником про: докладно про COVID-19 / ковід / коронавірус, доступно про COVID-19 / ковід / коронавірус (у таких еліптичних конструкціях 3 імпліцитним предикатом, що досить поширені в ролі заголовків до різноманітних матеріалів у медійному просторі, головний обставинний компонент адвербатив набуває особливої комунікативної значущості, виразно актуалізуючи чинники способу дії);

2) у формі родового відмінка:

- як безприйменниковий присубстантивний об'єктний компонент: поширення COVID-19 / ковіду / коронавірусу, статистика COVID-19 / ковіду / коронавірусу, симптоми COVID-19 / ковіду / коронавірусу, небезпека COVID-19 / ковіду / коронавірусу (крім об'єктності, родовий відмінок, послаблюючи семантику предметності іменника ковід, нашаровує значення атрибутивності, порівняймо: статистика ковіду / коронавірусу - ковідна / коронавірусна статистика, симптоми ковіду / коронавірусу - ковідні / коронавірусні симптоми, небезпека ковіду / коронавірусу - ковідна / коронавірусна набезпека); 
- як придієслівний / присубстантивний об'єктний компонент із прийменником від: померти / смерть від COVID-19 / ковіду / коронавірусу, одужати / одужання від COVID-19 / ковіду / коронавірусу, страхувати / страхування від COVID-19 / ковіду / коронавірусу, лікувати / лікування від COVID-19 / ковіду / коронавірусу;

3) у формі орудного відмінка як присубстантивний компонент 3 об'єктно-атрибутивною семантикою: пацієнт з COVID-19 / ковідом / коронавірусом, хворий із COVID-19 / ковідом / коронавірусом, боротьба з COVID-19 / ковідом / коронавірусом, ситуація з COVID-19 / ковідом / коронавірусом (порівняймо: ковідний / коронавірусний пацієнт, ковідний / коронавірусний хворий, ковідна / коронавірусна боротьба, ковідна / коронавірусна ситуачія);

3) у формі місцевого відмінка як присубстантивний компонент з об'єктно-атрибутивною семантикою: правила поведінки при COVID19 / ковіді / коронавірусі.

Аналіз лексичної сполучуваності абревіатури COVID-19 та лексичних варіантів іiі ковід і коронавірус з іншими словами дає підстави виснувати, що для цих лексем як абсолютно нових елементів у лексичній системі української мови характерна передусім роль залежного компонента в конструкціях вільного типу. До того ж відзначаємо відсутність уживання лексем ковід і коронавірус у формі множини, незважаючи на те що потенційно парадигма числа як граматичної категорії для іменника коронавірус у значенні власне медичного терміна все ж таки можлива. Наприклад: Коронавіруси (лат. coronaviridae) - родина одноланцюгових РНК-вірусів, що включає на травень 2020 року 43 види вірусів, об'єднаних у дві підродини Letovirinae ma Orthocoronavirinae (Вікіпедія); Коронавіруси (CoV) велика $i$ різноманітна група позитивно-полярних $P H K$ вірусів $у$ сімействі Coronaviridae (http://www.health-medix.com/articles/misteztvo/ 2015-10-17/Duda.pdf); Коронавіруси людини (НСоV) спочатку асоиіювали з помірними, локальними інфекиіями верхніх дихальних шляхів (Там само).

Констатуємо, що з-поміж лексичних варіантів абревіатури COVID-19 продуктивно вступає в атрибутивні відношення іменник коронавірус. Роль означення він виконує як у логічній, так і в образній вербальній конфігурації. Відповідно до змістового навантаження проаналізованого медіаматеріалу виокремлюємо кілька тематичних груп, що розкривають семантико-стилістичний потенціал цієї мовної одиниці.

Новинам власне медичного спрямування або іншим, що мають причиново-наслідковий зв'язок із хворобою, властиві такі 
словосполучення 3 компонентом коронавірус: коронавірусна інфекція, коронавірусна пандемія, коронавірусна хвороба. Наприклад: Часто пандемію COVID-19, викликану коронавірусною інфекцією SARS-CoV-2, порівнюють із війною, а лікарів - із солдатами на передовій (Український тиждень, 10.04.2020); А чи впоралися українські та світові медіа з новими обставинами та як коронавірусна пандемія та прийдешня криза далі вплинуть на журналістику й медіаринок, "Детектор медіа» запитав у медійних експертів (Детектор медіа, 13.05.2020); В Україні зафіксовано 2551 новий випадок коронавірусної хвороби COVID-19 (День, 09.09.2020). Контекстуально наведені словосполучення $\epsilon$ подібними, крім відмінності, закладеної в іменникові, що характеризує коронавірус як причину погіршення здоров'я, окреслює масштаб або спосіб поширення нового штаму хвороби.

Дотично до попереднього медичного блоку аналізуємо метафоризацію лексеми коронавірус, зрушення семантики якої відбувається переважно в заголовках новин у зв'язку з уживанням іiі в значенні психічного здоров'я населення. Нетипова та тривала ситуація планетарного масштабу 3 хронологічно та ситуативно невизначеним розвитком, безперечно, має вплив на емоційний стан людей. Поведінкові зміни відбито журналістами та блогерами в таких поєднаннях, як коронавірусна паніка, коронавірусна параноя, коронавірусний психоз. Наприклад: Коронавірусна паніка. У мережі показали, як в Данії штурмують супермаркети (відео) (Главком, 12.03.2020); Коронавірусна параноя, шторм $i$ ракета: фото дня (Кореспондент, 03.06.2020); «Коронавірусний психоз»: влада Білорусі заперечує небезпечність епідемї (hromadske.ua, 13.04.2020).

Вплив пандемії на світову економіку вербалізовано словосполученнями коронавірусна криза, коронавірусний фонд. Наприклад: Коронавірусна криза загрожує посилити голод у світі звіт ООН (DW, 13.07.2020); Грошей у коронавірусному фонді нема $(\mathrm{ZIK}, 12.09 .2020)$. Означення в цих контекстах необхідне для вказівки на причину фінансово-ресурсних глобальних змін. Вторинний наслідок пандемії, що стосується гальмування бізнесу, збитків, дефіциту, безробіття тощо, ускладнює перебіг довгострокового карантину, тому теж є темою журналістських матеріалів.

Щоденний кількісний підрахунок тих, хто захворів, одужав та/або помер унаслідок коронавірусної інфекції, $€$ невід'ємним атрибутом сучасного рейтингового медіаконтенту. Відтак активно вживаними від часу поширення хвороби стали словосполучення коронавірусний антирекорд, коронавірусний рекорд, коронавірусна статистика. Наприклад: 1967 нових випадків: в Украӥні- коронавірусний 
антирекорд (Львівський портал, 19.08.2020); На Буковині зафіксували «коронавірусний» рекорд (Українська правда, 03.09.2020); Два кольори коронавірусної статистики (Новинарня, 12.09.2020).

Художньо-філософського відтінку набувають сполучення коронавірусна епопея, коронавірусна трагедія. У такий спосіб автори текстів стилістично маркують опис ситуації. Наприклад: $У$ Дніпрянах триває "коронавірусна епопея» (Online Нова Каховка, 30.04.2020); Коронавірусна трагедія не повинна стати катастрофою людяності (НУБІП, 23.03.2020).

\section{5. Лексико-словотвірні особливості абревіатури COVID-19}

Під впливом світової пандемії коронавірусної хвороби українську мовну практику заполонили нові складні лексеми, що поєднують два іменники, перший з яких є прямим запозиченням абревіатури COVID у iii оригінальному англійському написанні й виражає атрибутивне значення (COVID-вакцина, COVID-відділення, COVID-заборона, COVID-ліжко, COVID-лікарня, COVID-патруль, COVID-nацієнт, COVID-показники, COVID-тести, COVID-фонд, COVID-центр, COVID-uцирра та ін.). Наприклад: Від багатих - біднішим: Китай приєднався до ініціативи щзодо COVID-вакцини (УКРІНФОРМ, 10.10.2020); В Ізраїлі “ультраортодокси” кидали у поліцію каміння $i$ металеві прути через COVID-заборони (УКРІНФОРМ, 10.10.2020); Половина COVID-ліжсок у лікарнях Львівщчини заповнені (УКРІНФОРМ, 10.10.2020); Кількість пацієнтів у COVID-лікарнях дуже швидко зростає - Степанов (УКРІНФОРМ, 02.10.2020); За добу госпіталізували 990 COVID-пацієнтів, найбільше за весь час пандемії-Степанов (УКРІНФОРМ, 10.10.2020); Лише в двох областях COVID-показники не перевищують базовий рівень (УКРІНФОРМ, 25.09.2020); Степанов: Приватні лабораторії не робитимуть COVIDтести людям з вулииі коштом МОЗ (УКРІНФОРМ, 10.10.2020).

До того ж усе частіше в інформаційному просторі можна натрапити на написання абревіатури коронавірусної хвороби в подібних складних іменниках малими літерами (covid-вакиина, covid-вiдділення, covidзаборона, соvid-ліжко, соvid-лікарня, соvid-nатруль, соvid-nацієнт, covid-показники, соvid-тести, covid-фонд, соvid-цеентр, covid-ųифра та ін.). Водночас у процесі освоєння цих новітніх запозичень у мовленні сучасних українців набуває значного поширення написання запозиченого новотвору COVID українськими літерами, наприклад: ковід-вакиина, ковід-відділення, ковід-заборона, ковід-ліжко, ковідлікарня, ковід-патруль, ковід-пацієнт, ковід-показники, ковід-прогноз, ковід-тести, ковід-урок, ковід-фонд, ковід-центр, ковід-цифра та ін. 
Проте зазначимо, що подібні утворення, незалежно від оформлення початкового компонента (COVID-naтруль / covid-nатруль / ковідпатруль), деструктивно впливають на українське прикметникове словотворення, оскільки є наслідком перенесення на грунт української мови словотвірної моделі англійської мови, й, на думку вченихмовознавців, «деформують системно зумовлену граматичну норму української літературної мови виражати атрибутивність за допомогою прикметника - спеціалізованого засобу реалізації ознаковості та обмежують відіменникове творення прикметників» ${ }^{20} .3$ огляду на це, замість початкового означального іменникового компонента COVID / covid / ковid, у названих та інших складних утвореннях потрібно віддавати перевагу спільнокореневому прикметникові ковідний.

Отже, ад'єктивно-субстантивні словосполучення ковідне відділення, ковідна лікарня, ковідний патруль, ковідний фонд, ковідний центр, ковідна цифрра тощо органічно відбивають самобутність національного словотворення. Закономірно, що сучасний інформаційний простір демонструє чимало прикладів використання таких конструкцій: Бергамо - ковідний цвинтар Європи (ТСН, 11.10.2020); Ковідна пневмонія має характерний вигляд $і$ на КТ ї̈ візуально ні з чим не сплутаєш (KURS, 05.09.2020); Паиієнти з підозрою на коронавірус можуть безкочтовно зробити комп 'ютерну томографію і рентген вони тепер увійшли до так званого "ковідного пакету" (Ірпінський вісник, 15.10.2020); ...обидва препарати на ринку давно, але наразі вчені вивчають ӥхню дію на «ковідних" пацієнтів, у яких є сериевосудинні патології... (УКРІНФОРМ, 01.08.2020); Зараз дівчина праџює в бригаді найвищого класу “C”, яка до того ж опікується екстреними “ковідними” викликами (Вінницький інформаційний портал «VЕЖА», 03.05.2020); Рано чи пізно комусь доведеться самостійно включати ковідний протокол, вдаватися до самоізоляиії та продовжувати роботу повністю віддалено (без паніки $i$ зайвих емоцій) (Юридична газета online, 13.10.2020) та ін.

У зазначених прикладах прикметник ковідний може бути замінений синонімним ад'єктивом коронавірусний. Наприклад, в одній зі статей Інформаційного агентства «Українські національні новини» ми натрапляємо на варіантне вживання цих синонімних слів: “Ковідний” фоно - це ноу-хау, яке запропонував колишній міністр фінансів та радник керівника Офісу Президента Ігор Уманський; Нагадаємо, колишній радник глави Офісу Президента Андрія Срмака Ігор Уманський, який днями звільнився, заявив, що кошти з коронавірусного

20 Городенська К. Нові явища та процеси в українському словотворенні: динаміка чи деструкція словотвірних норм? Украӥнська мова. 2013. № 2. С. 4. 
фонду, які виділили на будівництво доріг, привласнив так званий “картель” (IА «УНН», 21.11.2020). У цих прикладах прикметник ковідний у словосполученні ковідний фонд є тим мовним засобом, що замінює офіційну назву Фонду боротьби з гострою респіраторною хворобою COVID-19, спричиненою коронавірусом SARS-CoV-2, та ї̈ наслідками, мета якого - фінансування додаткових видатків на охорону здоров'я й соціальних видатків, безпосередньо пов'язаних із епідемією COVID-19, і так реалізує принцип мовної економії, спрямований, 3 одного боку, на швидке сприймання інформації, 3 другого - на синтаксичному рівні відбиває прагнення до економії фізичного простору.

\section{ВИСНОВКИ}

Лексикон сучасного українця протягом 2020 року поповнився новими словами на позначення коронавірусної хвороби, що спричинила світову пандемію та пов'язану з нею низку соціальних змін. Медичні терміни COVID-19 і коронавірус, закріплені в нормативно-правових документах і науковій медичній літературі, стали активним мовним засобом у публіцистичному й розмовному мовленні. Саме в медійному просторі, усемережжі й побутовому спілкуванні лексема COVID-19 набула стильових відтінків, реалізувала словотвірний потенціал, утворила варіанти слововживання та сформувала синонімні ряди. Зокрема, проаналізовані офіційні інтеренетові джерела, популярні новинні ресурси й контент соціальних мереж засвідчують, що лексеми COVID-19 і коронавірус активно використовують у текстах, де виникають семантичні зрушення, конотативні відтінки, лексичні новотвори 3 відповідними компонентами тощо.

Закріплені в мовленнєвій практиці українців слова на позначення актуальної для світу хвороби вже адаптовано до фонетичних, правописних і граматичних норм сучасної української мови, тож уживання їх є регулярним, нормативним і змістотвірним. Констатуємо, що в мові рівнозначно поширені англійськомовна абревіатура-термін COVID-19, лексичний відповідник коронавірус та адаптоване й закріплене в мовленнєвій практиці слово ковід, що є транслітерованим еквівалентом англійськомовної одиниці.

Тематичні лексичні елементи ковід, коронавірус, коронавірус COVID-19, коронавірус SARS-CoV-2, коронавірусна інфекиія 2019-nCoV, коронавірусна хвороба, коронавірусна хвороба COVID-19, гостра респіраторна хвороба COVID-19 формують синонімний ряд взаємозамінних термінів. Проте з метою мовної економії (компактного висловлення) мовці віддають перевагу однокомпонентним термінам. 
Варіантність смислових відношень і лексичної сполучуваності сприяє продукуванню контекстів, у яких лексеми COVID-19, ковід і коронавірус утворюють низку нових понять, пов'язаних із початком, перебігом чи наслідком захворювання. Авторська мовотворчість призводить і до вживання медичних термінів у метафоризованих словосполученнях, що надає інформації додаткової емоційності.

\section{АНОТАЦІЯ}

Дослідження присвячено лексичним, словотвірним і синтаксичним особливостям лексеми COVID-19, що виникла в мовленні українців у 2020 році внаслідок поширення коронавірусної інфекції. Абревіатуруініціалізм COVID-19 утворено від англійського термінасловосполучення coronavirus disease шляхом усічення перших двох літер двох коренів складного слова латинського походження coronavirus (укр. коронавірус) і першої літери наступного слова $\underline{\text { disease }}$ (укр. хвороба, захворювання) та з додаванням числа 19, що вказує на рік виявлення першого випадку захворювання. Цій абревіатурі властиве синонімне об'єднання лексем як інтернаціонального позначення, так i адаптованих українськомовних назв, з яких найбільш поширеними в аудіовізуальних і текстових джерелах $є$ слова ковід і коронавірус. Твірна основа ковід- має чималий дериваційний потенціал й активно вступає в словотвірні зв'язки, утворюючи за регулярними чи нерегулярними словотвірними моделями нові похідні, що використовують мовці в процесі спілкування. 3-поміж лексичних варіантів абревіатури COVID-19 продуктивно вступає в атрибутивні відношення іменник коронавірус, який виконує роль означення як улогічній, так і в образній вербальній конфігурації. Замість початкового означального іменникового компонента COVID / covid / ковід у складних утвореннях потрібно віддавати перевагу спільнокореневому прикметникові ковідний (ковідне відділення, ковідний фонд, ковідний центр).

\section{ЛІТЕРАТУРА}

1. Весна Т., Телецька Т. Лексичні інновації періоду коронавірусної пандемії. Записки з романо-германської філології. 2020. Випуск 1 (44). C. $82-89$.

2. Городенська К. Нові явища та процеси в українському словотворенні: динаміка чи деструкція словотвірних норм? Украӥнська мова. 2013. № 2. С. 3-11.

3. Денисенко М. П., Давиденко Н. В. Теорія поколінь та який іiі вплив на сучасний бізнес. Економіка та держава. 2020. № 1. С. 46-49. URL: http://www.economy.in.ua/pdf/1_2020/10.pdf. 
4. Дидик-Меуш Г. Сполучуваність vs комбінаторика для розвитку історії української мови. Україна: культурна спадщина, національна свідомість, державність / гол. ред. Ігор Соляр; НАН України, Інститут українознавства ім. І. Крип'якевича. Львів, 2019. Вип. 32. С. 293-303.

5. Козубай I. В., Хаджи А. Ю. Дослідження структурносемантичних особливостей новоутворень сучасної англійської мови. Вісник ЛНУ імені Тараса Шевченка. Філологічні науки. 2020. № 3 (334). C. $19-26$.

6. Коккіна Л. Р. Вербалізація концепту «пандемія COVID-19» у французькій мові як перекладацька проблема. International scientific and practical conference "Challenges of philological sciences, intercultural communication and translation studies in Ukraine and EU countries»: conference proceedings, October 30-31, 2020. Venice: Izdevnieciba «Baltija Publishing», 2020. P. 213-216. URL: http://baltijapublishing.lv/ omp/index.php/bp/catalog/view/69/1646/3656-1

7. Молоткіна Ю. О. Різні способи написання новітніх англіцизмів в українській мові. Науковий вісник ДДПУ імені І. Франка. Серія «Філологічні науки». Мовознавство. 2017. № 7. С. 119-123. URL: http://ddpu-filolvisnyk.com.ua/uploads/arkhivnomerov/2017/NV_2017_7/31.pdf

8. Ніколаєва Т. М. Перекладацькі аспекти сучасний англійських абревіацій. Науковий вісник Міжнародного гуманітарного університету. Серія «Філологія». 2018. № 37. Т. 3. С. 107-109. URL: http://www.vestnik-philology.mgu.od.ua/archive/v37/part_3/27.pdf

9. Нові слова та значення : словник / Ін-т укр. мови НАН України ; уклали: Л. В. Туровська, Л. М. Василькова. Київ: Довіра, 2009. 271 с.

10. Омельчук С. А. Відіменникові ад'єктиви «пандемічний» i «пандемійний» у сучасному українському лексиконі. Актуальні питання суспільних наук та історії медицини. Спільний украӥнськорумунський науковий журнал. Серія "Філологічні науки" || Current issues of Social studies and History of Medicine. Joint Ukrainian-Romanian scientific journal. Series "Philological sciences" / Редколегія: А. Мойсей, Ш. Пуріч. Чернівці-Сучава: БДМУ. 2020. № 3 (27). С. 15-18.

11. П'ятецька О. Українське законодавство в умовах національного карантину: лексико-семантичний аналіз. Актуальні питання гуманітарних наук. 2020. Вип 30. Том 3. С. 36-40.

12. Тур О. Інтернет-сайти як джерело поповнення загальномовного словника лексичними скороченнями. Тези 72-ої наукової конференції професорів, викладачів, наукових працівників, аспірантів та студентів університету, присвяченої 90-річчю Національного університету «Полтавська політехніка імені Юрія Кондратюка» (Полтава, 
21 квітня - 15 травня 2020 р.). Полтава: Національний університет імені Юрія Кондратюка, 2020. Том 2. С. 311-312.

13. Український правопис / НАН України. Київ : Наук. думка, 2019. С. 90.

14. Хода Л. Мова реклами в часи пандемії коронавірусу COVID-19 (на матеріалі українських та словацьких текстів). Південний архів (філологічні науки). 2020. № 82. С.130-134.

Information about authors: Omelchuk S. A., Doctor of Pedagogical Sciences, Associate Professor, Professor at the Department of Slavic Philology and World Literature named after Professor Oleh Mishukov, First Vice-Rector Kherson State University 27, Universytetska, Kherson, 73003, Ukraine

Mandych T. M., Postgraduate Student at the Department of Ukrainian Philology and Journalism Kherson State University 27, Universytetska, Kherson, 73003, Ukraine 